\title{
关于开展我国入海大河河口研究的問題
}

\author{
郭 敬 輝
}

（中国科学院地理研究所）

\section{一 我国入海大河河口研究的畫义}

河口是河流与海洋的接触地区，它他括入海河流 的近游地段 (河口三角洲及潮水区) 及口外滨海前䋹。 由于它道常是內河和海上航运的枢紐，現在世界上大 約一牛以上的大商港和三分之一以上的超过百万人口 的大城市都位于河口，很多国家的㴡業基地也大都位 于河口; 又由于河口是通向外洋的阴戶，所以在国防上 也非常重要。許多河口三角洲都是最肥沃的土地，加上 这些比区便于利用河水进行灌溉，在农業上也有極其 重要的价值。因此大河入海的河口区一三角洲地带 往待是很多国家的精华所在。但由于河口区是河川径 流、潮汐和海浪的冲突地带, 时嫦遭受水次, 而造成白 大琏失, 更由于河流泥沙的下泻使航道不易稳定, 且易 移生岸壁诗嚗現象, 甚至阻塞航道, 妨碍航行; 潮汐 卜溯又易使土淁盐漬化，影响农業生产。因此，入海 入沙河口的研究, 引起了世界很多国家的注意。

我国河流众多，其出口又大都在㧴国东部沿海， 由大河构成的河口区及三伤洲是我国目前工業和农業 最腾达的地区。但我国河口具有泥沙多、潮汐大、風 注影响严签和类型复杂的特征, 在利用和改造上都存 任:着行多困难問題。如上游是世界有名的大都市，但 由于河口拦門沙（主要是銅沙难）水浅和黃浦江航道 的不稳定, 以致上海的港口情况与这个大城市的投展 情况極不适应; 同时河口段江陰以下也胄于泥沙的移 动，泣溜多变，影响航运和沿岸筑港。大洁口的泥沙 更为严重, 拦阴沙經常变动, 泥沙的回淤使塘沽新港 不得不进行长期的与經常的挖泥工作。辽河口泥沙的 将寒情况也将严重地影响到松辽运河和辽南运河开鳘 后的通航。錢塘江口是一个浊潮河口，泥沙来回动蕩于 涌斗形的海灣和河口，不但产失了它的航运价值和渗 業价值, 同时也造成两岸农田诗埸的严重現繁。珠江口 的㴤沙情况也很严, 重更由于河口受台風影响, 时常造 成严重次害。黃河口义是一种特殊类型, 河道变迁不 定, 洪水期間到处漫溢, 远不能适应黄河流域远景規 划中發展航运的要求。此外，中国其他河流的河口对

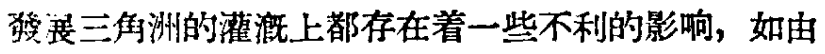
于海潮倒灌使土壤盐婊化, 阻水下泻形成泛监, 泥沙
淤积影响挡潮開的修建等。因此，叒展我国大河河口 的研究極为重要。

\section{二大河河口研究的国际、国內情况}

在河口上大港口的建筑和航运条件的改善，是任 十九世紀中叶由于航运的儛展与船只吃水深度的垥 加, 首先在法国与英国的河口开始的。他們根据河口 研究的初步結論, 进行了模型試艆, 然后再进行港口 的修建. 美国河口的研究和在河口上建筑的工程，大 致也朵用了欧洲同样的办法。他們的研究虽然出过一 些錯裐，但終于使他們以后的建筑有了把握，持使建 筑物和建筑物保养的費用縮小到最低限度。在苏联， 由于大部分河口是非潮汐河口，因此进行研究和建筑 工程便简单得多; 但关于河口的研究在沙皇时代即已 开始, 对各河口区的港口建筑和防洪的斗爭起了很大 的作用。但当时的研究是很片面的, 只有在十月革命 后 1930-1940 年間，由于注意到大河河口的綜合利 用，这方面的研究工作才有了較大的成就。目前苏 联水文气象总合海洋研究所設有河口研究組，其任务 是对所有河口研究工作方法上、理論上的指导，以及 綜合整理河口覌測站的資料; 苏联科学院主席团海洋 研究委員会河口組，負資推动和协調各部門对河口的 研究工作; 在重要河口上設立有三个河口研究站，都 配备有机动的运輸工具; 扭在大河河口上㪣有众多的 覌測站, 在研究工作中采用了示棕原子和磷光体等先 进方法探索泥沙的来龙去脉。1951-1955 年在 鄂本 河、勒拿河、叶尼塞河、北德維䄲河、黑龙江等河流 的河口进行了大胃模的調查工作。近年来还出版了許

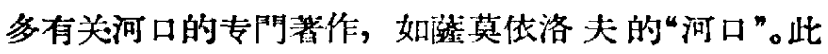
外, 只研究伏尔加河口的論著, 即这 175 万字。抹經 常向有关部門提红实际的建議。

中国入海大河河口的問題如此严重, 在实 践上 又如此重要，但我国过去对河口的研究工作則进行得 極少。解放前即使有一些研究工作, 也多为外国人所 作, 甚至河口的观測和調查工作也完全掌揘在帝国主 义之手, 虽然长期以来各地区也积照了不少資料, 但 也很少加以䍜集、整理、分析, 进行有系統的研究。 截至目前为止, 河口設站問題份汥有統一規划, 对泥 
沙移动胃律份未学揘，改善梳道的研究工作做得很少， 甚至訢多河口梳道情况日形恶劣; 河口浩成的灾害也 未能有效的防止，各大河流的流域规划都未将河口区 列为重点之一，甚至未将河口段包括在流域規划之內，

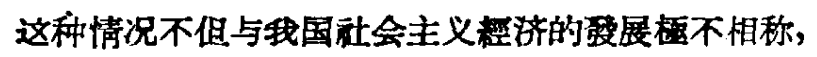
同时这种情况如不改变, 也将給台敏解放海运陽通以

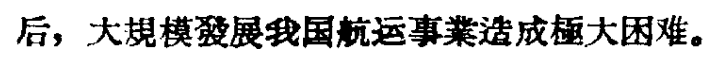

1956年夏, 中国科学院中国自然区划工作委員会

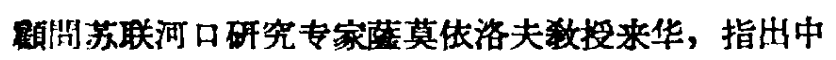
国河口研究的追切性和重要性, 引起了我国水利、航 运、軍事等部䅀的重視, 因此中国科学院生物地学部 得得蘶氏同意, 于 1957 年 3 月 11 日到 4 月 5 日在华 东水利学院举办了河口研究报告会, 中国科学院地理 研究所和海洋生物研究所、水利部䅀、交通部門、水 产部閒、海露部門及有关高等学校 116 人考加, 由中 国专家报告了中国各大河口的情况和存在問題，听 取了专家的講演，采統地传投了河口研究的理論和方 法。会后扭由蔯莫依洛夫数投指导，在长江口、錢境 江口和海河口进行了实地考察。钡过此次学㚙和考察 后, 人椚更梁刻地了解到河口研究的重要, 井初步学 習了河口研究的理論和方法。在专家的指导和水利部 的支持下，在杭州建立了鐵境江河口研究站，由南京 水利科学研究所項导, 現已开始了錢塘江河口的全面 調查和研究。

\section{三 我国大河河口研究工作应 包括的主要内容}

1.我国大河河口資料的整理和匯䄇，包括：大河 河口三角洲自然地理情况、地質地貌情况、河口水文 情况（海洋的河流的）、泥沙移动和河休变形情况。

2. 河口及三角洲地区自然地理和粰济地理的調查 研究。包括：地質构造、第四紀地質、地貌（河口三 角洲的磷育、河口水下三角洲的变迁)、气候、上壤、 生物及大河河口区祭济地理的調查和研究.

3. 我国入河河口自然历史的研究。包括: 历史上 河口的向外伸展及其速度、出海口和水道的变化及其 原因、水准点的上升或下降、历史上河口区的洪水灾 害、历史上河道通航情况, 以及由于以上的变化所引 起的河口三角洲經济情况的变化。

4. 关于河口設站的規划。包括: 站网布置見划、 覌測見范的制言丁、覌測仪器的研究等。

5. 河口水流动力学和泥沙的研究。包括: 潮汐和 经流的相互影响对泥沙的移动、河休变形、泥沙运动 应用示踪原子方法的研究、潮汐河口模型試驗、風浪 对水工建筑物的破坏和影响、利用風浪改进泥沙淤 积、保护海岸和海㙈的研究等。
6. 强潮河口（錢塔江口、长江口）的研究。包括: 湖汐形成、潮浪演进、进潮量、潮洺对泥沙和岸雔冲

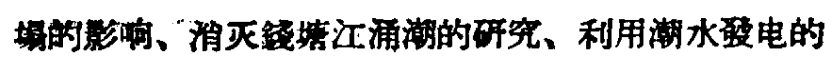
研究等。

7. 河口三角洲發展农田灌沘和防止洪水灾害問题 的研究。包括: 防止士堆盐清化、酸展潮田、淤沙对 河口灌渠的影响、对水工建筑物的危害、洪水頊报和 預防等。

8. 我国大河径流得到調节后，对河口影响的研 究。包括: 河床刷深和河口水文的变化、对灌溉和航 运的影响、护岸措施和河口变形問題、漁業的变化。

9. 大河口区水化学、水生物的研究。

\section{四应有的具体措施}

1. 考虑到河口研究工作的重要和关采到部多部门

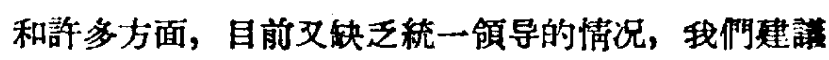
国务浣科学规划委員会水工組应邀請有关河口研究的 专家, 拟定河口科学研究的中心問題說明書, 明确河 口研究的任务, 中心問題机构建立和研究分.工, 标将 此說明蓄呈报国务院科学規划委員会, 补充到科学筧 划中去, 以便将河口的研究和利用納入国家的整个科 学研究計划。

2. 貄立研究机构, 最好是指定水利部和交通部共 同領导的南京水利科学研究所专門谄責河口研究，梘 定一定数量的科学研究干部、㯨䩀和必要的設备, 使

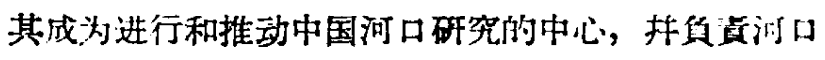
覌測资料的整挶。中国科学院海洋生物研究所和地理 轵究沂等单位也应根据需要和何能活当配合, 共河选 一两个大河口进行研究。

3. 在第二个五年計划內, 应在我国除践境汇口以 外的其他五大河口（辽河口、海河口、黄河口、长江 口、珠江口）逐步建立河口研究站。栍据各河口存在 閣昆的性質分别由水利部鬥或交通部門的研究机构領 导, 进行覌測和研究. 还应以各大河口为中心, 激請 有关单位参加, 建立河口研究协調小緗, 組織各方面 力量共同进行研究。此外, 沿海各省水利厅(局)、各大 河河口港务局、各大河流域的水利研究和勘测設計机 构等部門, 对自己所轄各河口亦应指定专人进行研究。

4. 为了促进河口的研究, 可由上述組織机构在一 定时期內召开河口研究学术钨論会, 玤出版有关河口 研究的著作和交流河口研究的情报。

5. 干部培养，高等学筊与河口有关的系科专㴽 （陆地水文专業, 海洋专業、水港专業等) 在教高 划或数学入絧中应增加河口的課程或数学內容，以便 培美对河口研究有一定理論水年的干部，同时还产选 派研究生或进焦生到苏联学㼭. 